\title{
Species Identification of Rock Oysters Collected from the Dhofar Region, Sultanate of Oman
}

\author{
Mikhail V. Chesalin*, Salem A. Al-Ghassani, \\ and Mohammed A. Balkhair
}
Fisheries Research Center-Salalah, Ministry of Agriculture and Fisheries Wealth, P.O. Box 33, PC 217, Salalah, Sultanate of Oman

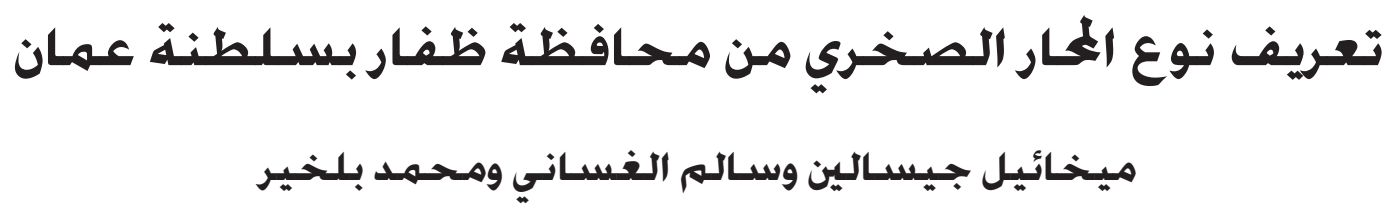

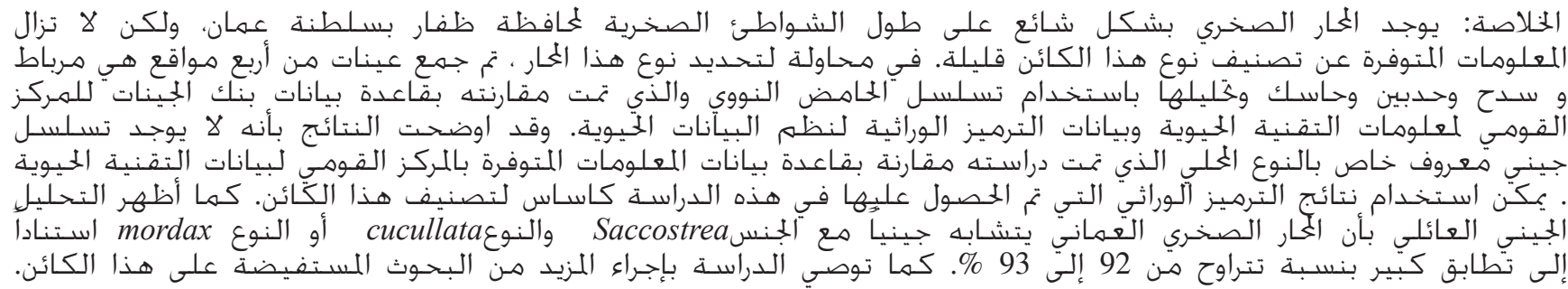

$$
\text { كلمات مفتتاحية: الغار الصخـري، ترهيز الخمـض النووي ، عـمان }
$$

\begin{abstract}
Oysters are commonly found on rocky shores along the Dhofar coast of Oman, but the species composition has not yet been studied. In an attempt to determine the species of these oysters, samples from four sites (Mirbat, Sadah, Hadbin, and Hasik) were collected and analyzed using DNA sequences that were compared with the database of GenBank/National Center for Biotechnology Information (NCBI) and Barcoding of Life Data Systems (BOLD). BLAST results of DNA sequences showed that there were no existing sequences available on NCBI/GenBank and BOLD. The DNA barcode sequences generated in this study can be employed as standards for this species and may be of use in taxonomic studies. Phylogenetic analysis demonstrated that the oysters from Oman exhibit homology with Saccostrea species cucullata or mordax.
\end{abstract}

Keywords: Rock oyster, DNA barcoding, Oman.

\section{Introduction}

Rock oysters are distributed along the coastline of the Dhofar region in southern Oman. These edible mollusks are common and abundant and are collected for human consumption from rocky shores and roots of mangroves in the intertidal zone. In addition, due to their ability to accumulate different pollutants from the surrounding marine environment they are used as bioindicators in different monitoring programs in Oman (Burns et al., 1982; Fowler, 1988; Fowler et al., 1993; Badawy and Al-Harthy, 1991). In most previous studies in Oman the rock oyster was described as the hooded oyster Saccostrea cucullata (Born, 1778), which is widely distributed in the littoral zone of Indo-Pacific, Eastern Atlantic, and the Mediterranean. The species composition of rock oysters in Omani waters has not yet been studied. There are 15 species of true oysters (family Ostreidae) known from the Indian Ocean and Indo-Pacific region (Huber, 2010;
WoRMS http://www.marinespecies.org). Much of the oyster classification to date is based on shell characteristics, but due to their sensitivity to environmental factors and the plastic nature of their shells, morphological identification of rock oysters is difficult. The effect of the environment upon valve morphology in oysters can be distinct (Seilacher et al., 1985) and this has led to many errors and general confusion in oyster classification (Wang and Guo, 2008). Oysters are thus notorious for profound nomenclatorial confusion regarding species identities (Lam and Morton, 2004). Phylogenetic analyses using partial mitochondrial 16S DNA sequences of approximately 513 base pairs of Saccostrea populations in Australia recognized at least three different species (Lam and Morton, 2006). NA barcode sequence technique was used for oyster species identification and taxonomy (Cordes et al., 2005; Lam and Morton, 2006; Wang and Guo, 2008; de Melo et al., 2010; Liu et al., 2011). This technique uses a set 
of primers to amplify a 648-base pair (bp) region of the mitochondrial cytochrome-c oxidase subunit 1 (COI) gene to ensure the identification of a wide range of biological specimens rapidly and accurately. This technique is known as "DNA barcoding". The Barcode of Life project was proposed to promote DNA barcoding as a global standard for sequence-based identification of eukaryotes. In 2004, this project was formally initiated by the establishment of the Consortium for the Barcode of Life (CBOL), which aims to develop a standard protocol for DNA barcoding and to construct a comprehensive DNA barcode library (Jinbo, 2011).

The DNA barcode sequence database for the identification of species is maintained by the Barcoding of Life Data Systems (BOLD) and is accessible to the scientific community. Identification of unknown samples involves DNA extraction and amplification of the COI gene with universal primers and subsequent sequencing of the gene. The sequence is compared with the database from GenBank/National Center for Biotechnology Information (NCBI) or BOLD using online search tools. As this process is basically based in comparison of DNA sequence data, it is of utmost importance that the sequence database of NCBI and BOLD should be enriched by contributions from all over the world.

This study was carried out to identify the rock oyster distributed in Dhofar region of Oman and to determine if there is more than one species of oysters in this area.

\section{Materials and Methods}

\section{Sample Collection}

Ten individuals from each of four different sites in Dhofar region (Mirbat, Sadah, Hadbin, and Hasik) of the rock oyster were collected randomly from the rocks in the intertidal zone and placed in clean polythene bags in 2010 . In the laboratory, tissues were removed with stainless steel instruments and rinsed quickly in distilled water before being placed in special preservation tubes provided by Advanced Biotechnology Center (ABC, Dubai, UAE). In total 40 samples were analyzed in the $\mathrm{ABC}$.

\section{Sample Preparation and DNA Extraction}

Ten to $20 \mathrm{mg}$ of tissue samples from each specimen were removed using sterilized scalpels. The tissue was lysed with about $200 \mu \mathrm{l}$ of lysis buffer by incubation at $55^{\circ} \mathrm{C}$ for three hours. The DNA extraction was performed using the phenol chloroform method.

\section{PCR Amplification}

The PCR amplification was carried out using universal primers recommend by CBOL. $0.5 \mu \mathrm{l}$ of DNA template was used for a $25 \mu \mathrm{l}$ reaction.

\section{PCR Product Purification}

PCR product was purified using ExoSap/Promega SV Gel extraction and a PCR purification kit.

\section{Cycle Sequencing PCR and DNA}

DNA sequencing was carried out only with forward primers of the universal primers selected for analysis. Sequencing was performed according to standard protocol provided for by the Big dye terminator $\mathrm{kit}^{\circledR} \mathrm{V} 3.1$ (ABI Prism 3100 Genetic analyzer). The reaction products were cleaned using the of ethanol precipitation method to remove unincorporated ddNTPs.

The data was analyzed with ABI Sequencing Analysis V 5.2 software. The sequence edition and multiple sequence alignment were done with BioEdit and MEGA software.

The sequence data was compared with the NCBI/ GenBank (http://www.ncbi.nlm.nih.gov) data base using BLAST (Basal locus alignment search tool) and with the database from BOLD.

\section{Results and Discussion}

The DNA barcode (COI) sequence for the rock oyster species studied (673 base pairs) is listed below:

GATATTGGAAGTTTTTACATAGTTTTTGGGTTTT GATCAGTTTTGGCTGGGAAAAAAATCAGATCGT TGATTCGATGAAGACTTTTCAACCCAGGAGCTA AGTTTTTAGACCCTGTGTGTTACAATGCAGTGG TAACTATACACGCTTTGGTTATAATTTTCTTTTT TGTTATGCCTGTAATAATTGGAGGATTTGGTAA CTGATTAGTGCCGCTGATACTCGAGGTGCCTGA TATGCAATTTCCACGAGTTAACGCTTTTAGGTT CTGAGTCTTGCCTGCGTCTCTTTATTTTATAGGA ATTTCTGGGTTTGTAGAAAATGGAGTGGGGGCC GGTTGAACTATTTACCCTCCGCTATCAACCTTTT CTTATCACGGTATGTGTATGGATTTGGCTATTC TAAGTTTACACTTAGCTGGGATTAGGTCGATTTT TAGATCAATCAATTTTATGGTGACTATTAAGAA TATACGTTCCGTAGATGGTCATCTATTGAGGTT ATTCCCATGGTCTATTAAAGTAACTTCTTTTTTGT TGCTTACAACTTTACCTGTTTTAGCCGGTGGGCT TACTATGCTTTTAACTGATCGACATTTTAATACTT CATTTTTTGACCCAGTGGGTGGTGGGGATCCGGT TTTATTTCAGCACCTATTTTGATTTTTTGGTCACC

The sequence data obtained was compared with the NCBI database and BOLD database (http: //www.ncbi.nlm.nih.gov/) using BLAST (Basal Locus Alignment Search Tool) and with ABC data base from BOLD. 
Table 1. Top five matches of the rock oyster from the Dhofar region.

\begin{tabular}{|c|c|c|c|c|c|}
\hline Phylum & Class & Family & Genus & Species & $\begin{array}{c}\text { Specimen Similarity } \\
(\%)\end{array}$ \\
\hline Mollusca & Bivalvia & Ostreidae & Saccostrea & cucullata & 93.41 \\
\hline Mollusca & Bivalvia & Ostreidae & Saccostrea & mordax & 92.32 \\
\hline Mollusca & Bivalvia & Ostreidae & Saccostrea & kegaki & 83.41 \\
\hline Mollusca & Bivalvia & Ostreidae & Dendrostrea & frons & 79.53 \\
\hline Mollusca & Bivalvia & Ostreidae & Ostrea & angasi & 78.76 \\
\hline Mollusca & Bivalvia & Ostreidae & Ostrea & edulus & 78.51 \\
\hline
\end{tabular}

The comparison with the BOLD species revealed that the specimens fall under Phylum Mollusca and Class Bivalvia, Family Ostreidae; with maximum homology with S. cucullata at $93.41 \%$ similarity (Table 1, Figure 1). The neighbor-joining tree generated using BOLD is given in figure 2.

The phylogenetic tree generated using highly similar sequences from NCBI/GenBank using the Kimura2 parameter through MEGA software is given in figure 3. The comparison with the sequence data base of NCBI/ GenBank revealed maximum homology with genus Saccostrea and species cucullata and mordax at approximately $92-93 \%$ similarity.

Thus, the study revealed that there were no previous sequences available for the rock oyster from Dhofar region on NCBI/GenBank and BOLD. As very good barcode sequences for the species have been generated in the study it would be the first barcode sequence for this species. The rock oyster in the studied areas in Dhofar region falls under the classification of species $S$. cucullata or $S$. mordax with a high similarity of $92-93 \%$ provided by the analysis conducted. All species from the different

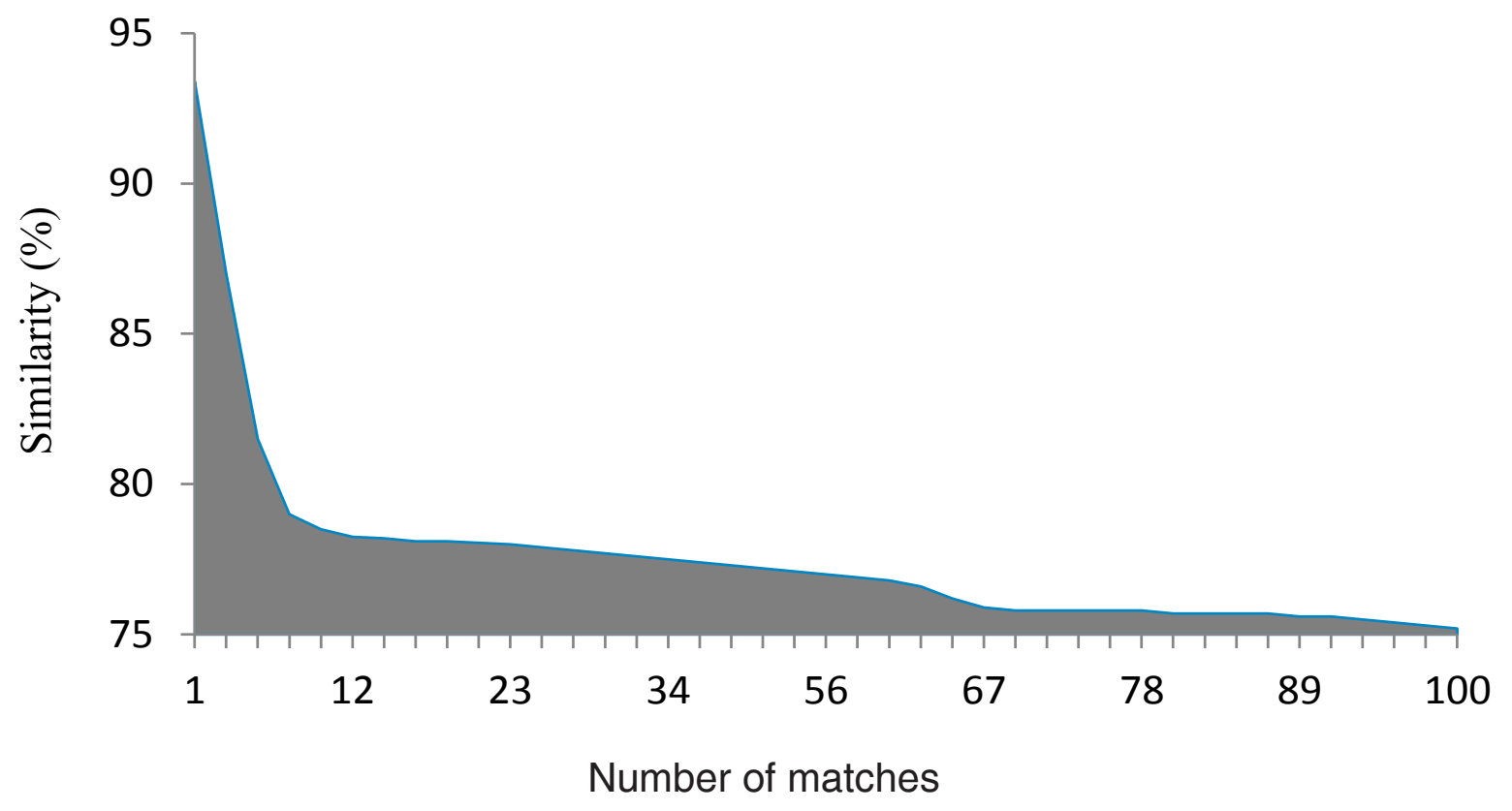

Figure 1. Similarity scores of the top 100 matches of the rock oyster from Dhofar. 


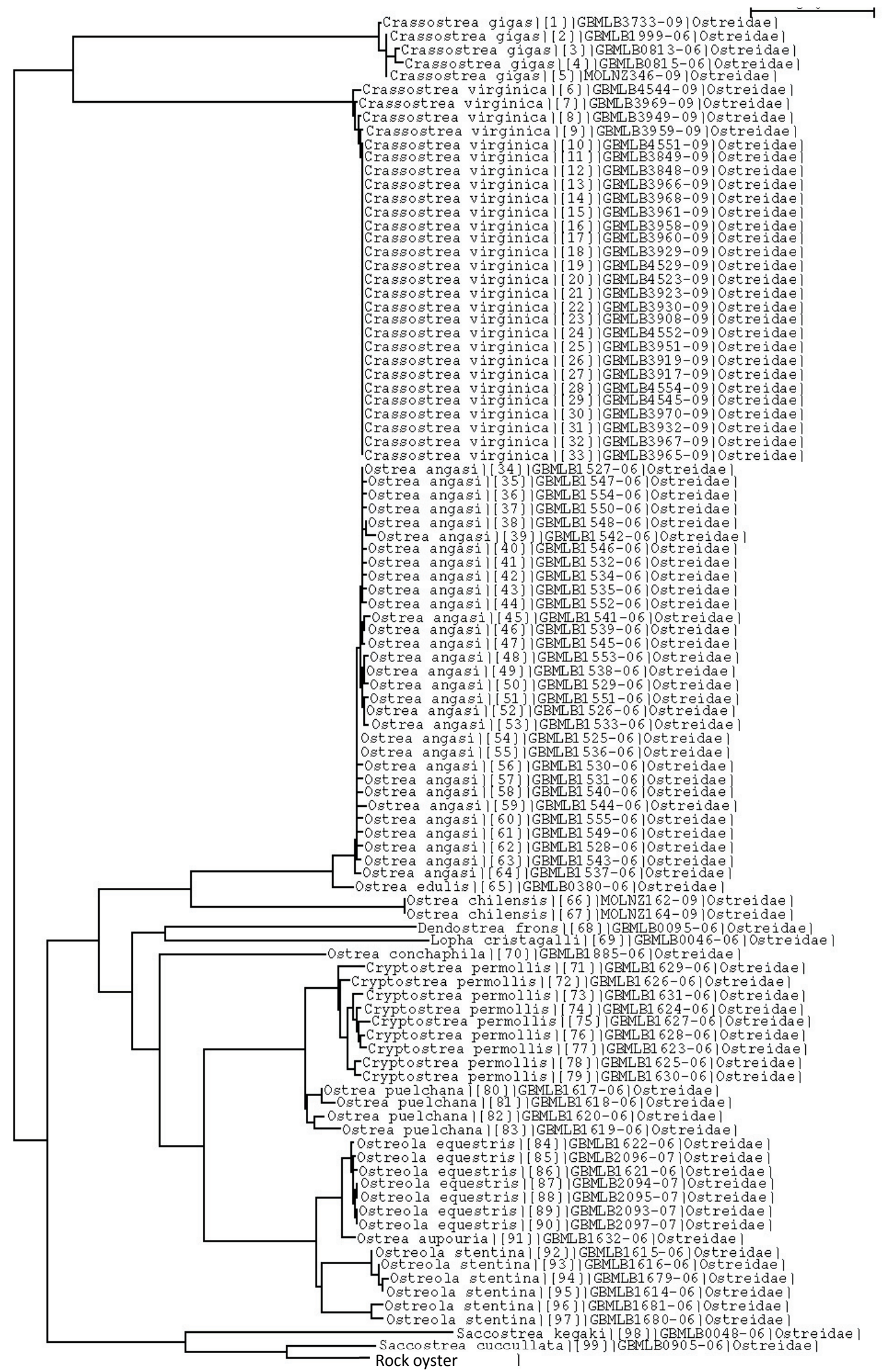

Figure 2. Neighbor-joining tree of the rock oyster from Dhofar based on identification through BOLD. 


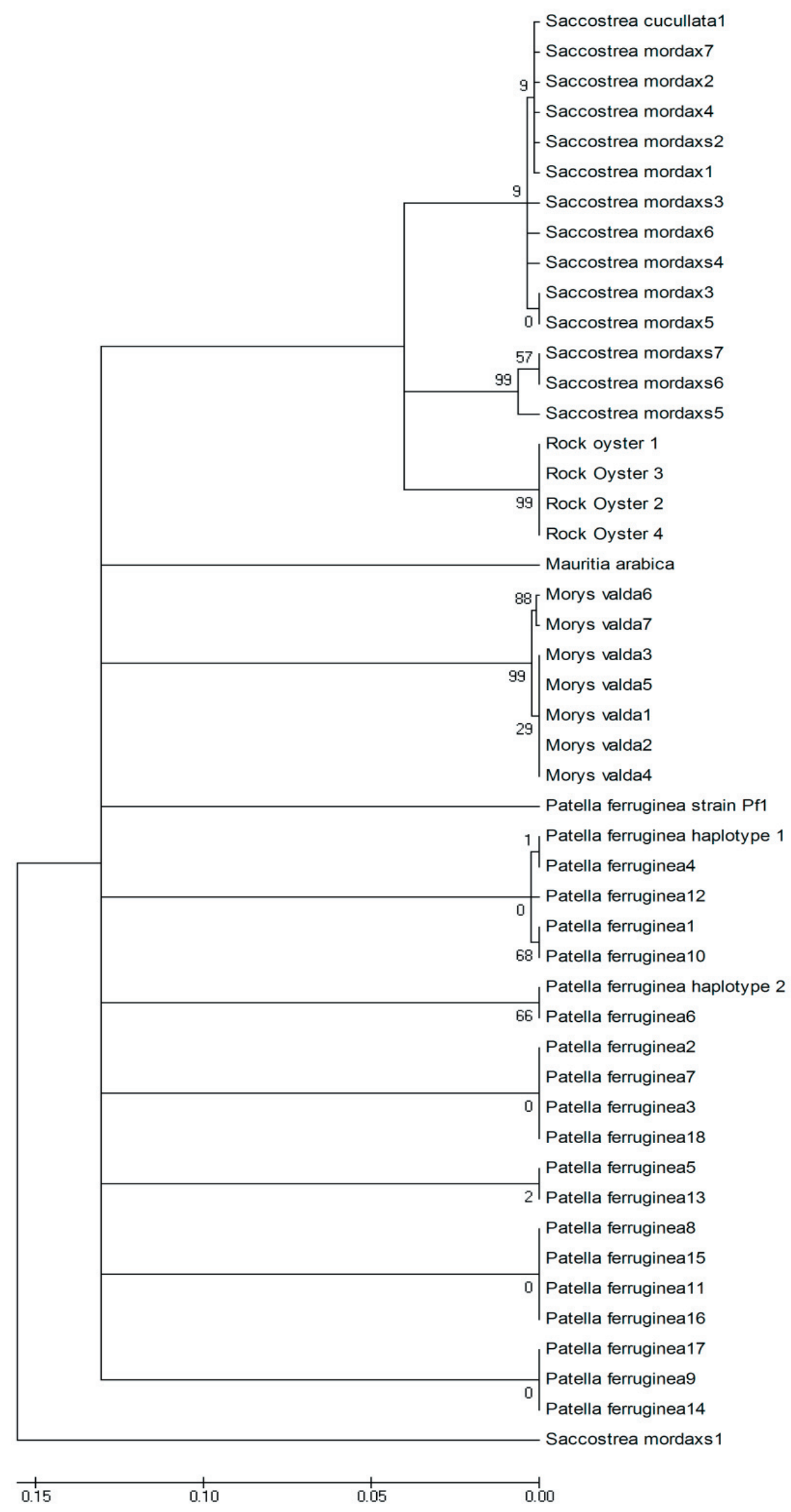

Figure 3. Phylogenetic tree generated using Kimura 2 parameter with MEGA from highly similar sequences from NCBI. 
areas of study had the same classification, but further studies should be conducted to confirm these findings.

\section{Acknowledgments}

Thanks are due to the Advance Biotechnology Center (Dubai, UAE) for analyzing the samples and the Agriculture and Fisheries Research Fund for financial support of this study. Thanks are also extended to Salem Kahoom and Ali Rajab from the Fisheries Research Center-Salalah for helping in sample collection and Dr. Schalk de Waal for reading the manuscript.

\section{References}

Badawy, M.I. and F.T. Al-Harthy. 1991. Hydrocarbons in seawater, sediment, and oyster from the Omani coastal waters. Bulletin of Environmental Contamination and Toxicology 47(3):386-391.

Burns, K.A., J.P. Villeneuvea, V.C. Anderlin and S.W. Fowler. 1982. Survey of tar, hydrocarbon and metal pollution in the coastal water of Oman. Marine Pollution Bulletin 13:240-247.

Cordes, J.F., J.B. Stubbs and K.S. Reece. 2005. Phylogenetics and species identification of Crassostrea oysters based on sequences and PCR-RFLP analyses of ITS-1 and COI markers. Journal of Shellfish Research 24:647.

de Melo, A.G, E.S. Varela, C.R. Beasley, H. Schneider, I. Sampaio, P.M. Gaffney, K.S. Reece, and C.H. Tagliaro. 2010. Molecular identification, phylogeny and geographic distribution of Brazilian mangrove oysters (Crassostrea). Genetics and Molecular Biology 33:564-572.

Fowler, S.W. 1988. Coastal baseline studies of pollutants in Bahrain, UAE and Oman. In: Proceedings of Symposium on Regional Marine Pollution Monitoring
Research Programmes,155-180. Al-Ain, UAE, Dec. 1985. ROPME /GC-4/2, ROPME, Kuwait.

Fowler, S.W., J.W. Readman, B. Oregioni, J.P. Villeneve, and K. Macky. 1993. Petroleum hydrocarbons and trace metals in near shore Arabian Gulf sediment and biota before and after the 1991 war: An assessment of temporal and spatial trends. Marine Pollution Bulletin 27:171-182.

Huber, M. 2010. Compendium of bivalves. A Full-color Guide to 3,300 of the World's Marine Bivalves. A Status on Bivalvia after 250 Years of Research. ConchBooks, Hackenheim, Germany. 901pp.

Jinbo, U., T. Kato, and M. Ito. 2011. Current progress in DNA barcoding and future implications for entomologyens. Entomological Science 14:107-124.

Lam, K. and B. Morton. 2004. The oysters of Hong Kong (Bivalvia: Ostreidae and Gryphaeidae). The Raffles Bulletin of Zoology 52:1-28.

Lam, K. and B. Morton. 2006. Morphological and mitochondrial-DNA analysis of the Indo-West Pacific rock oysters (Ostreidae: Saccostrea species). Journal of Molluscan Studies 72:235-245.

Liu, J., Q. Li, L. Kong, H. Yu, and X. Zheng. 2011. Identifying the true oysters (Bivalvia: Ostreidae) with mitochondrial phylogeny and distance-based DNA barcoding. Molecular Ecology Resources 11:820-830.

Seilacher, A., B.A. Matyja, and A. Wierzbowski. 1985. Oyster beds: morphological response to changing substrate condition. In: Sedimentary and Evolutionary Cycles. U. Bayer and Seilacher (Editors). Lecture Notes in Earth Sciences 1:421-435.

Wang, H. and X. Guo, 2008. Identification of Crassostrea ariakensis and related oysters by multiplex speciesspecific PCR. Journal of Shellsh Research 27:481-487.

Received: February 20, 2012

Accepted: May 5, 2012 